\title{
Current Control for Single-Phase Active Filter Based on Multirate PWM
}

\author{
Kimihiko Sato Student Member (Yokohama National University, kimi@hfl.dnj.ynu.ac.jp) \\ Hiroshi Fujimoto Member (Yokohama National University, hfuji@ynu.ac.jp)
}

Keywords: active filter, line current detection, PWM hold, deadbeat control, multirate control, repetitive control

Current harmonics generated by nonlinear loads or some switching devices of power electronics system may increase power losses or cause damages to electrical equipments. Thus, active filter (AF) have been proposed in order to compensate the harmonics.

The shunt active filter, which is connected to power systems in parallel with the load, is considered as a current source. However, the shunt active filter is actually realized by current control using the voltage source type inverter.

Authors applied multirate perfect tracking control (PTC) to current control of the shunt active filter. Although conventional singlerate deadbeat control could not guarantee zero tracking error for arbitrary reference signals, the proposed multirate control can achieve perfect tracking at every sampling point.

In this paper, the current reference is produced by using the periodicity of the harmonics. Two repetitive controls the feedforwardtype (FF-type) compensation and the feedback-type (FB-type) compensation are proposed. The proposed method is applied to the shunt $\mathrm{AF}$ in simulations and experiments.

Fig. 1 is the circuit of the single-phase AF. AF is shown in the dotted line, which is composed by the voltage type inverter and the output filter. And Fig. 2 shows experimental device.

Fig. 3(a), (b), (c) show the line current $i_{s}$. We find that the harmonic component is compensated. The harmonic component is compensated at some level with the FF-type compensation. On the other hand, we find that the harmonic componet is compensated completely with the FB-type compensaion and Q filter. Experimental results show the effectiveness of the proposed method.

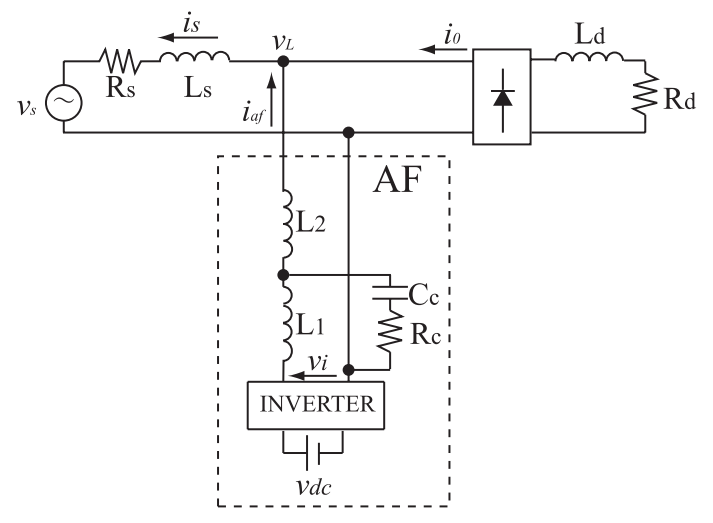

Fig. 1. Circuit of the single-phase active filter

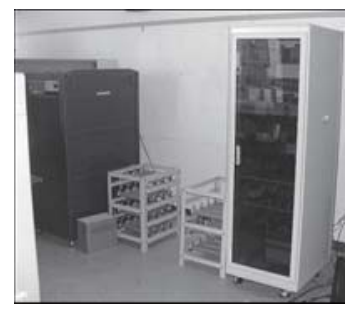

Fig. 2. Experimental device

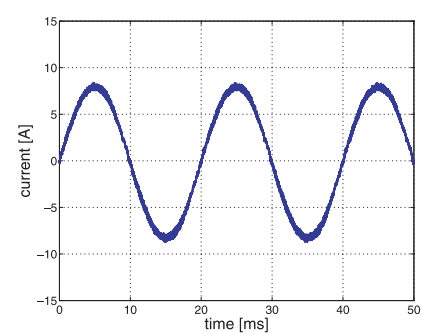

(c) With AF. (FB-type)

Fig. 3. Line current $i_{s}$ (Experiment) 


\section{マルチレートPWMに基づく \\ 単相アクティブフィルタの電流制御法}

学生員 佐藤 公彦* 正 員 藤本 博志*

\section{Current Control for Single-Phase Active Filter Based on Multirate PWM}

Kimihiko Sato*, Student Member, Hiroshi Fujimoto*, Member

The shunt active filter, which is connected to power systems in parallel with the load, is considered as a current source. However, the shunt active filter is actually realized by current control using the voltage source type inverter. Authors applied multirate perfect tracking control (PTC) to current control for the shunt active filter. Although conventional single-rate deadbeat control could not guarantee zero tracking error for arbitrary reference signals, the proposed multirate control can achieve perfect tracking at every sampling point. In this paper, we propose a novel method to generate repetitive compensation signals. Simulations and experiments are shown to verify the effectiveness of the proposed method.

キーワード：アクティブフィルタ, 電源電流検出, PWM ホールド, デッドビート制御, マルチレート制御, 繰り返し制御

Keywords: active filter, line current detection, PWM hold, deadbeat control, multirate control, repetitive control

\section{1. 序論}

現在，各種電気機器等から発生する高調波が問題になっ ている。高調波はインバータ駆動の電動機で余分な損失を 増加させたり，機器の損傷等を引き起こす可能性がある。 そこで, 高調波補償装置としてアクティブフィルタ（以下， AF）を用いることが研究されている(1)。

主流である並列形 $\mathrm{AF}$ は，電源と負荷に対して並列に接 続され，電流または電圧の高調波成分を検出して系統の高 調波電流を補償する電流を流す制御を行うものである。並 列形 $\mathrm{AF}$ は電流源としてみなせるが，具体的に電流源とし て動作するには電圧型インバー夕を用いた回路での電流制 御によって実現される(2)。本稿では，電源側電流検出一括 補償方式 (3)によって電流指令值を演算し, 並列形 $\mathrm{AF}$ の出 力電流 $i_{a f}$ が指令值に追従するようにインバータを用いて 制御する。

$\mathrm{AF}$ のディジタル電流制御についての研究は, 近年提案さ れたものとしてオーバーサンプリングを用いた制御 (4) や, 従来から研究されているものとしてはデッドビート制御を 用いること (5)(6) などが提案されている。しかし, 従来用いら れているデッドビート制御 (7)では，プラントの条件によっ ては不安定零点 ${ }^{(8)}$ 等の影響によりフィードフォワード制御

\footnotetext{
* 横浜国立大学

厂 240-8501 横浜市保土ヶ谷区常盤台 79-5

Yokohama National University

79-5, Tokiwadai, Hodohaya-ku, Yokohama 240-8501
}

部が不安定となり，誤差なく指令值に追従することはでき ない(9)。

そこで著者らはマルチレートフィードフォワード制御を 用いノミナルプラントに対してサンプル点ごとに追従誤差 が零になることを保証した完全追従制御 (PTC) 法 ${ }^{(10)}$ を AF に適用している ${ }^{(11)}$ 。本稿では，高調波が周期的であること を利用して補償信号指令值を作り出す。指令值生成方法に ついてはフィードフォワード型とフィードバック型という 2 種類を提案する。その指令值に対して PTC 法によるディ ジタル電流制御を行い, 整流器負荷からの高調波を補償で きることをシミュレーションと実験を通して解析を行う。

\section{2. 電源側電流検出方式 ${ }^{(3)}$}

本稿で用いた単相 AF の回路を Fig. 1 に示す。点線内が $\mathrm{AF}$ であり, 電圧型インバータと出力フィルタにより構成 される。各素子等のパラメータは Table 1 であり, 高調波 発生源として単相ダイオード整流器を用いた。

並列形 $\mathrm{AF}$ は系統の高調波を補償するように電流を出力 する。AF 出力電流 $i_{a f}$ の指令值 $i_{a f}^{*}$ を作り出すためには高 調波の検出が必要である。まず, 基本波成分 $i_{s f}$ と高調波成 分 $i_{s h}$ が含まれた電源側電流 $i_{s}$ を検出し, Discrete Fourier Transform（DFT）により $i_{s f}$ を求める。

$i_{s}$ から $i_{s f}$ を除去することにより求めた高調波成分 $i_{s h}$ の 逆相を $i_{a f}^{*}$ とする。

$$
i_{a f}^{*}[k]=-i_{s h}[k]=-\left(i_{s}[k]-i_{s f}[k]\right)
$$




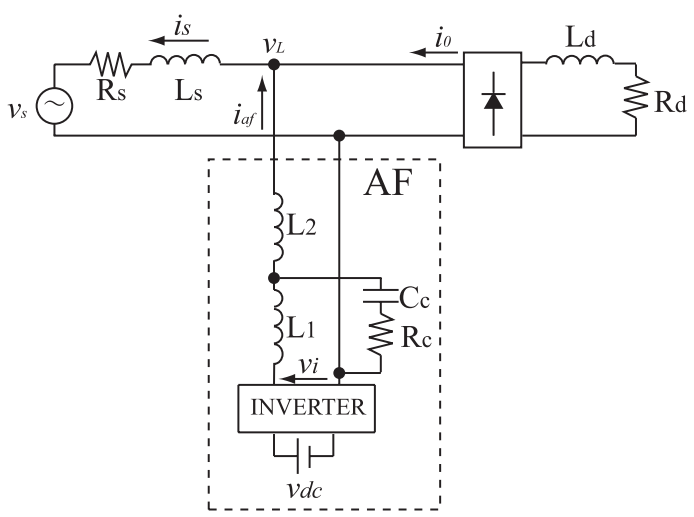

Fig. 1. Circuit of the single-phase active filter.

Table 1. Parameters table.

\begin{tabular}{ll|ll}
\hline$L_{s}$ & $3.18 \mathrm{mH}$ & $R_{s}$ & $0.1 \Omega$ \\
\hline$L_{1}$ & $700 \mu \mathrm{H}$ & $L_{2}$ & $500 \mu \mathrm{H}$ \\
\hline$C_{c}$ & $1.25 \mu \mathrm{F}$ & $R_{c}$ & $4.0 \Omega$ \\
\hline$v_{d c}$ & $150 \mathrm{~V}$ & $v_{s}$ & $100 \mathrm{~V}, 50 \mathrm{~Hz}$ \\
\hline
\end{tabular}

\section{3. シングルレート制御系設計}

〈3・1〉 シングルレート系での制御対象のモデル化 $\quad i_{a f}$ を制御するために Fig. 1 での AF 設置点の電圧 $v_{L}$ までの回 路である Fig. 2 を用いる。電圧 $v_{i}$ はインバー夕の出力電圧 であり， $\mathrm{AF}$ 外部の情報は $v_{L}$ で表され，系統・負荷の条件 によらずに $\mathrm{AF}$ の電流制御を考えることができる ${ }^{(5)}$

入力を $v_{i}, v_{L}$, 出力を $i_{a f}$ としてプラントの伝達関数を求 めると (2) 式となる。

$$
\begin{gathered}
i_{a f}=P_{i}(s) v_{i}-P_{l}(s) v_{L} \cdots \\
P_{i}(s)=\frac{b_{i 1} s+b_{i 0}}{s^{3}+a_{2} s^{2}+a_{1} s} \\
P_{l}(s)=\frac{b_{l 2} s^{2}+b_{l 1} s+b_{l 0}}{s^{3}+a_{2} s^{2}+a_{1} s}
\end{gathered}
$$

ただし $, a_{1}, a_{2}, b_{i 0}, b_{i 1}, b_{l 0}, b_{l 1}, b_{l 2}$ はすべて Fig. 2 の 回路パラメータから決定される定数である。

本節では，まず簡単化のため (2) 式の $v_{L}$ の項を外乱項と して無視し， $v_{i}$ により $i_{a f}$ を制御する。しかし実際には $v_{L}$ の項は無視できないので，その対策については第 5 節で述 ベる。

$$
v_{L} \text { の項を無視すると, (3) 式となる。 }
$$

$$
i_{a f}=\frac{b_{i 1} s+b_{i 0}}{s^{3}+a_{2} s^{2}+a_{1} s} v_{i}
$$

状態変数を

$$
\begin{aligned}
x_{1} & =\frac{1}{b_{i 1} s+b_{i 0}} i_{a f} \\
x_{2} & =\dot{x}_{1} \cdots \cdots \\
x_{3} & =\ddot{x}_{1} \cdots \cdots
\end{aligned}
$$

として連続時間系での状態方程式を求めると, (7) 式が得ら れる。

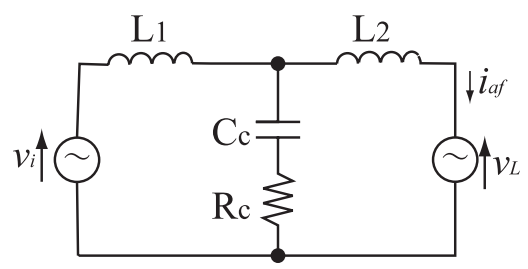

Fig. 2. Equivalent circuit of current $i_{a f}$ control.

$$
\begin{aligned}
& \dot{\boldsymbol{x}}(t)=\boldsymbol{A}_{p} \boldsymbol{x}(t)+\boldsymbol{b}_{p} v_{i}(t), i_{a f}(t)=\boldsymbol{c}_{p} \boldsymbol{x}(t) \cdots \cdots \\
& \boldsymbol{A}_{p}=\left[\begin{array}{ccc}
0 & 1 & 0 \\
0 & 0 & 1 \\
0 & -a_{1} & -a_{2}
\end{array}\right], \boldsymbol{b}_{p}=\left[\begin{array}{lll}
0 & 0 & 1
\end{array}\right]^{T}, \\
& \boldsymbol{c}_{p}=\left[\begin{array}{lll}
b_{i 0} & b_{i 1} & 0
\end{array}\right], \boldsymbol{x}=\left[\begin{array}{lll}
x_{1} & x_{2} & x_{3}
\end{array}\right]^{T}
\end{aligned}
$$

制御対象を離散化する場合，一般的には零次ホールドを 用いるが，インバータシステムにおいては $v_{i}(t)$ は $\pm V_{d c}$ か 0のいずれかの值しか取れないため，瞬時值を緻密に制御 したい場合には，零次ホールドによる平均的な離散化近似 は不適切である。そこで， $\Delta T[k]$ を制御入力 $u[k]$ としてと らえた PWM ホールドを用いて離散化を行う ${ }^{(12)}$ 。制御対象 を PWM ホールドを用いて制御周期 $T_{u}=54.2 \mu \mathrm{s}$ で離散化 すると (8) 式が得られる。 $\Delta T[k]$ はパルスの時間幅であり, 以後, $u[k]$ は $\Delta T[k]$ として扱う。

$$
\begin{aligned}
& \boldsymbol{x}[k+1]=\boldsymbol{A}_{s} \boldsymbol{x}[k]+\boldsymbol{b}_{s} u[k], i_{a f}[k]=\boldsymbol{c}_{s} \boldsymbol{x}[k] \\
& \boldsymbol{A}_{s}=e^{\boldsymbol{A}_{p} T_{u}}, \boldsymbol{b}_{s}=e^{\boldsymbol{A}_{p} \frac{T_{u}}{2}} \boldsymbol{b}_{p} V_{d c}, \\
& \boldsymbol{c}_{s}=\boldsymbol{c}_{p}, u[k]=\Delta T[k]
\end{aligned}
$$

〈3・2〉 フィードバックデッドビート制御 (7) フィード バックデッドビート制御（以下，FBDB）は従来のディジ 夕ル電流制御 (5)(6) に用いられている制御則である。これを 今回用いるプラントに適用する。

離散化された状態方程式である (8) 式より， $i_{a f}[k+1]$ に ついて解くと (9) 式のように表される。

$$
i_{a f}[k+1]=\boldsymbol{c}_{s}\left(\boldsymbol{A}_{s} \boldsymbol{x}[k]+\boldsymbol{b}_{s} u[k]\right)
$$

ここで, $i_{a f}[k+1]=i_{a f}^{*}[k+1]$ として $u[k]$ について解くと (10) 式になる。

$$
u[k]=\frac{i_{a f}^{*}[k+1]-K_{1} x_{1}[k]-K_{2} x_{2}[k]-K_{3} x_{3}[k]}{K_{4}}
$$

ただし， $K_{1} \sim K_{4}$ はすべて回路パラメータとサンプリング 周期から決定される定数である。

FBDB では $r[k]$ から $u[k]$ までのフィードフォワード制御 部の伝達関数がプラントの逆システムに相当している。こ れにより，入力に目標值の 1 サンプル先を与えることでサ ンプル点ごとに目標值に追従する。

しかし, 今回用いたプラントの伝達関数 (3) 式を離散化す ると零点が $z=-1.30,-0.24$ となっている。すなわち, プラ ントの逆システムであるフィードフォワード制御部の極が 


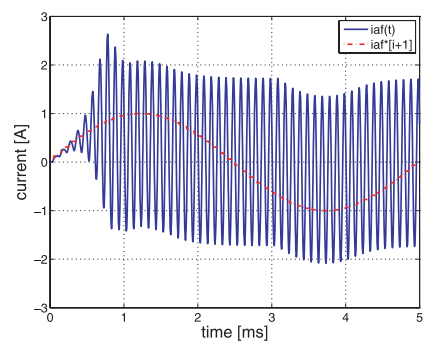

Fig. 3. Simulation results with FBDB.

$z=-1.30,-0.24$ ということになり, 不安定な極 $(z=-1.30)$ を持っていることがわかる。

実際に目標值として振幅 $1 \mathrm{~A}$ ，周波数 $200 \mathrm{~Hz}$ の正弦波を 入れて FBDBを用いてシミュレーションを行うと Fig. 3 の ようになり, 出力が発散して不安定になってしまう。この ことから，シングルレート制御系では任意の指令值に対し て完全追従することができないことが明らかとなった。

\section{4. マルチレート制御系設計}

〈4・1〉 マルチレート制御系での完全追従制御 (PTC) ${ }^{(10)}$ これまで述べてきたように，従来用いられていたシング ルレート制御系では，外乱やモデル化誤差がない理想的な 場合でも，短いサンプリング周期で離散化をしたときに生 じる不安定零点の影響により任意の指令值に対して誤差零 で追従することは理論的に不可能である。

そこで本稿ではマルチレート制御系を適用することによ り任意の指令值に対して完全追従を達成する。マルチレー ト制御系は Fig. 4 に示すように指令值のサンプリング周期 $T_{r}$ の間に制御入力を $n$ 回切り替える制御法である。ただ, $n$ はノミナルプラントの次数であり, ここでは $n=3$ であ る。キャリア周期 $T_{u}$ と指令值のサンプリング周期 $T_{r}$ と出 力周期 $T_{y}$ の間には $T_{u}=\frac{T_{r}}{3}=T_{y}=54.2 \mu \mathrm{s}$ の関係がある。

(8) 式において 3 サンプル目について考え, $x[i]=\boldsymbol{x}\left(i T_{r}\right)$ とおくと

$$
\begin{aligned}
& \boldsymbol{x}[i+1]=\boldsymbol{A} \boldsymbol{x}[k]+\boldsymbol{B} \boldsymbol{u}[k] \ldots \ldots . \\
& \boldsymbol{A}=\boldsymbol{A}_{s}^{3}, \boldsymbol{B}=\left[\boldsymbol{A}_{s}^{2} \boldsymbol{b}_{s}, \boldsymbol{A}_{s} \boldsymbol{b}_{s}, \boldsymbol{b}_{s}\right], \\
& \boldsymbol{u}[i]=\left[\begin{array}{c}
u_{1}[i] \\
u_{2}[i] \\
u_{3}[i]
\end{array}\right]=\left[\begin{array}{c}
\Delta T[k] \\
\Delta T[k+1] \\
\Delta T[k+2]
\end{array}\right]
\end{aligned}
$$

となり,さらに (11) 式を $\boldsymbol{u}[i]$ について解くと (12) 式が得 られる。

$$
\boldsymbol{u}[i]=\boldsymbol{B}^{-1}\left(\boldsymbol{I}-z^{-1} \boldsymbol{A}\right) \boldsymbol{x}[i+1] .
$$

(12) 式のすべての極は $z$ 平面で原点にあることから安定 な逆系であることが分かる。また，制御対象の状態変数に 対する目標軌道の予見值 $\boldsymbol{r}[i]=\boldsymbol{x}_{d}[i+1]$ を入力に与えると, フィードフォワード制御入力は (13) 式のようになる。

$$
\boldsymbol{u}_{0}[i]=\boldsymbol{B}^{-1}\left(\boldsymbol{I}-z^{-1} \boldsymbol{A}\right) \boldsymbol{r}[i]
$$

これより，ノミナルプラントに対してサンプル点ごとに

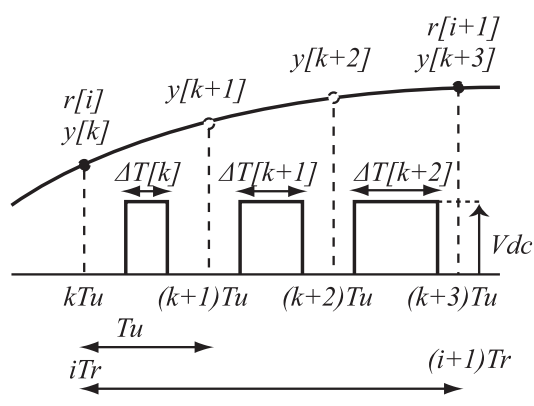

Fig. 4. Multirate PWM control.

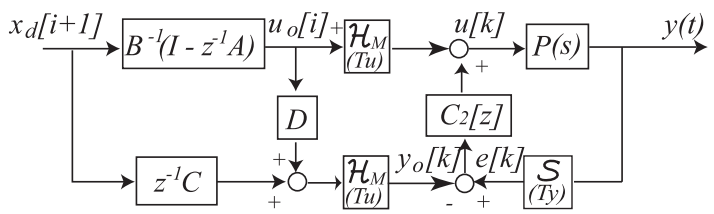

Fig. 5. Block diagram of PTC.

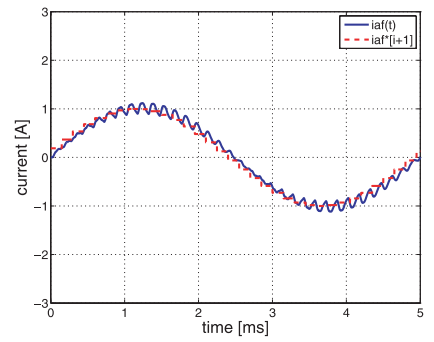

Fig. 6. Simulation results with PTC.

完全追従が達成される。PTC のブロック図は Fig. 5 のよう に表され，外乱やプラント変動によって出力に誤差が生じ た場合フィードバック制御が動きその誤差を抑圧すること ができる。

$\langle\mathbf{4} \cdot \mathbf{2}\rangle$ 状態変数目標軌道生成 PTCでは入力に制御 対象の状態变数に対する目標軌道の予見值を与える。状態 変数は (4) (6) 式であり, 状態変数の指令值は電源側電流 検出方式より導出した $i_{a f}^{*}$ から求める。すなわち

$$
x_{1}^{*}=\frac{1}{b_{i 1} s+b_{i 0}} i_{a f}^{*}
$$

として状態変数の指令值 $x_{1}^{*}$ を与える。

ここで，(14) 式の伝達関数は 1 次遅れ系であり，その カットオフ周波数約 $200 \mathrm{kHz}$ は今回用いたキャリア周波数 約 $20 \mathrm{kHz}$ に比べて十分はやいので, 直流ゲインである

$$
x_{1}^{*}=\frac{1}{b_{i 0}} i_{a f}^{*}
$$

に近似できる。

同様に，(16)，(17) 式より $x_{2}^{*} ， x_{3}^{*}$ をえる。

$$
\begin{aligned}
& x_{2}^{*}=\frac{1}{b_{i 0}} \dot{i}_{a f}^{*} \\
& x_{3}^{*}=\frac{1}{b_{i 0}} \ddot{i}_{a f}^{*}
\end{aligned}
$$

シングルレート制御系での FBDB のときと同様に，目標 
值として振幅 $1 \mathrm{~A}$ ，周波数 $200 \mathrm{~Hz}$ の正弦波を入れて上記の ように状態変数目標軌道を作り，PTCを用いてシミュレー ションを行った結果がFig. 6 である。発散することなくサ ンプル点ごとに誤差なく追従していることが確認できる。

\section{AF 外部を考慮した制御系設計}

$\left\langle\mathbf{5 \cdot 1 \rangle}\right.$ 外乱項の補償法 前章までは (2) 式において $v_{L}$ の項を外乱項として考慮せず制御系設計を行っていた。本 節からは Fig. 1 の点線に示す $\mathrm{AF}$ 外部の回路も考慮するた めに $v_{L}$ の項についての補償制御を行う。

$\mathrm{AF}$ 外部の回路も考慮した場合，(2) 式より，出力 $i_{a f} に$ は $v_{L}$ の項も影響する。よって，この項が出力に影響を及ほ さないように補償する必要がある。

そこで，提案する制御法ではあらかじめ目標軌道として $i_{a f}^{*}$ に $v_{L}$ の項を足し合わせたものを与える。(2)式より

$$
i_{y}:=i_{a f}+P_{l}(s) v_{L}=P_{i}(s) v_{i}
$$

と変形し，PTCを用いて $v_{i}$ により $i_{y}$ をその目標軌道に追 従させる。すなわち，(15) 式として与えていた $x_{1}^{*} を(19)$ 式として与える。

$$
x_{1}^{*}=\frac{1}{b_{i 0}} i_{y}^{*}=\frac{1}{b_{i 0}}\left(i_{a f}^{*}+P_{l}(s) v_{L}^{*}\right) .
$$

これにより，出力時に $v_{L}$ の項の影響を相殺して打ち消すこ とができ， $i_{a f}$ を指令值に追従させることが可能になる。

$\langle\mathbf{5} \cdot 2\rangle$ 補償信号指令值生成 PTC を用いる際，目標 軌道の 1 サンプル先の予見值が必要である。目標值は (19) 式であり， $x_{1}^{*}[i+1]$ を作り出すためには $i_{a f}^{*}[i+1]$ と $v_{L}^{*}[i+1]$ を与えなければならない。

まず， $v_{L}^{*}[i+1]$ について考える。 $v_{L}$ は高調波に影響され る波形となるが，高調波を完全に補償できたとすると基本 波成分のみとなるはずである。そこで, DFT を用いて $v_{L}$ の 基本波成分 $v_{L f}$ を求め，(20) 式より $v_{L}^{*}[i+1]$ を与える。

$$
v_{L}^{*}[i+1]=v_{L f}\left(t+T_{r}\right)
$$

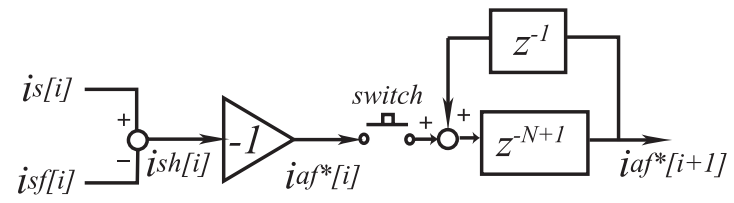

Fig. 7. Block diagram of $i_{a f}^{*}[i+1]$
次に, $i_{a f}^{*}[i+1]$ についてであるが, 本稿ではスイッチン グによるフィードフォワード型の補償と繰り返し制御器が 学習をし続けることによるフィードバック型の補償という 2 種類について検証を行う。

〈5・2・1〉 フィードフォワード $(\mathbf{F F})$ 型＼cjkstart電源側電流 検出方式から作り出される $i_{a f}^{*}[i]$ は系統電源の基本波 1 周 期分で周期的である。そこで，1 周期間だけスイッチをオ ンにして $i_{a f}^{*}$ をモリに蓄え，その信号を順番に出力する ことで指令值を作り出す。これはフィードフォワード補償 となる。 $i_{a f}^{*}[i+1]$ は Fig. 7 に示すように

$$
i_{a f}^{*}[i+1]=i_{a f}^{*}[i-N+1] \cdot
$$

として得られる。ここで， $N$ は基本波周期 $T$ あたりのサン プル数 $N=T / T_{r}=123$ である。

$\langle\mathbf{5 \cdot 2 \cdot 2 \rangle}$ フィードバック（FB）型上記の方法で補 償信号指令值を生成することで理想的には高調波を完全に 補償できるが，実際には整流器負荷からの電流が変化し高 調波が残ってしまう。そこで，FF 型ではオフしていたス イッチをオンにし続けることにより完全に高調波を除去す ることを考える。 FF 型に対し，この補償はフィードバック 的に繰り返すことで指令值を生成する。 $i_{a f}^{*}[i+1]$ は Fig. 7 のスイッチをオンし続けることにより

$$
i_{a f}^{*}[i+1]=i_{a f}^{*}[i-N+1]-i_{s h}[i-N+1] \cdots
$$

として得られる。

FB 型の場合，基本波の整数倍の高調波を抑圧することが できるが，次数間高調波成分に対しては悪化させてしまう という問題点がある ${ }^{(13)}$ 。

\section{6. シミュレーションおよび実験}

〈6・1〉 シミュレーションシミュレーションにはパ ワエレ用回路シミュレータPSIM を用いた。

Fig. 8(a)，(b)，(c) は AFオフ時と AF オン時でのそれぞ れの電源側電流 $i_{s}$ の波形であり，それぞれを FFT 解析し たものが Fig. 9(a)，(b)，(c)である。Fig. 8(a)の AFなしの 時に比べ，FF 型の補償信号生成を行った時にはある程度 の高調波を補償できてはいるが，まだ $0 \mathrm{~A}$ 付近のところが 歪んでおり高調波が残っていることがわかる。これは整流 器負荷からの電流が若干ではあるが変化したためである。 Fig. 9(b) からもそのことはわかる。それに対し, Fig. 8(c),

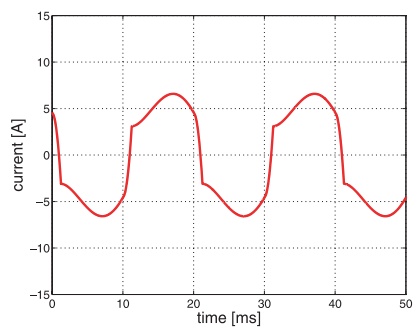

(a) Without $\mathrm{AF}$

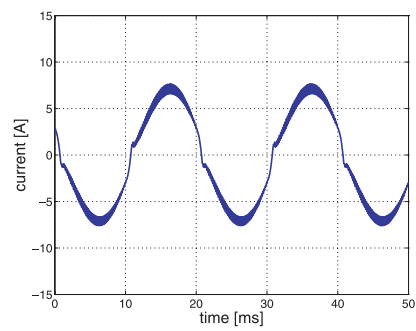

(b) With AF. (FF-type)

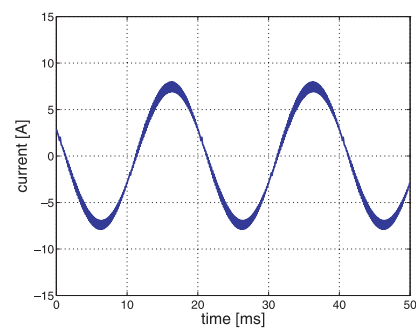

(c) With AF. (FB-type)

Fig. 8. Line current $i_{s}$ (Simulation) 


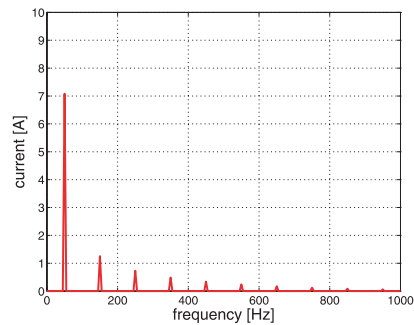

(a) Without AF.

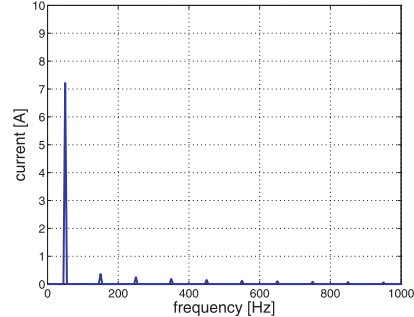

(b) With AF. (FF-type)

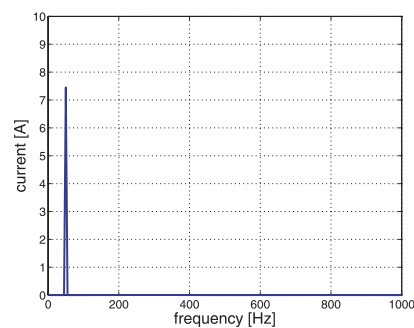

(c) With AF. (FB-type)

Fig. 9. FFT analysis $i_{s}$ (Simulation).

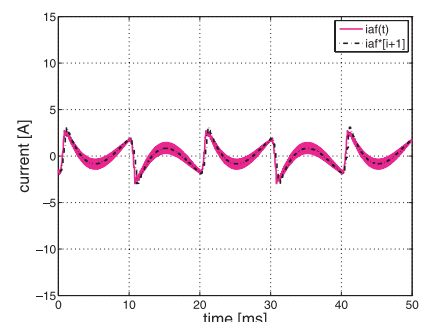

(a) FF-type

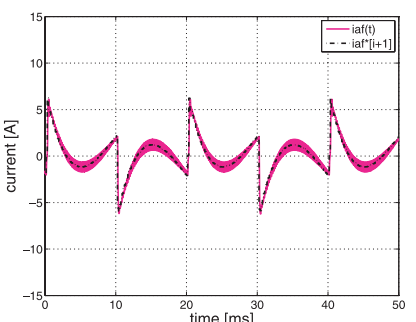

(b) FB-type

Fig. 10. AF current $i_{a f}$ (Simulation).

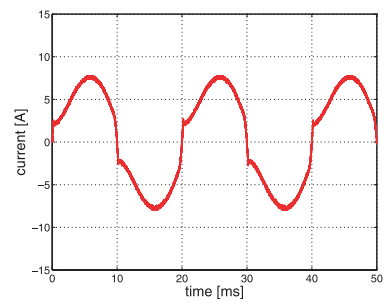

(a) Without AF

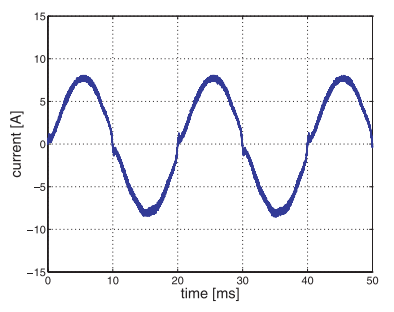

(b) With AF. (FF-type)

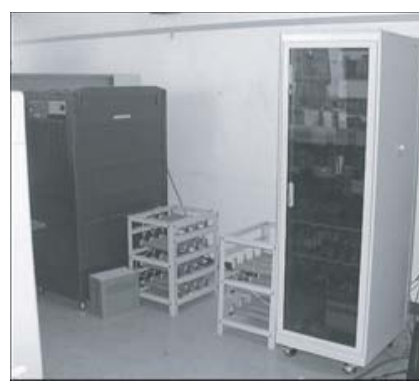

Fig. 11. Experimental device.

Fig. 12. Line current $i_{s}$ (Experiment).

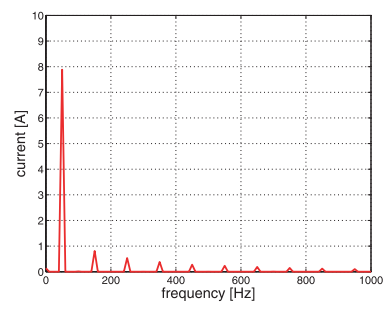

(a) Without AF

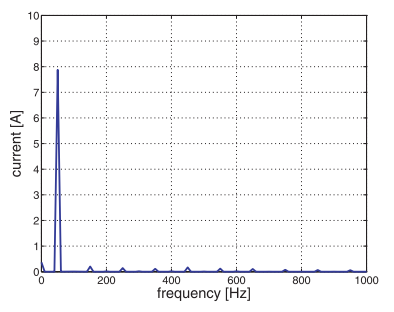

(b) With AF. (FF-type)

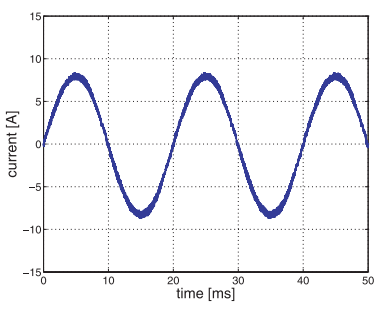

(c) With AF. (FB-type)

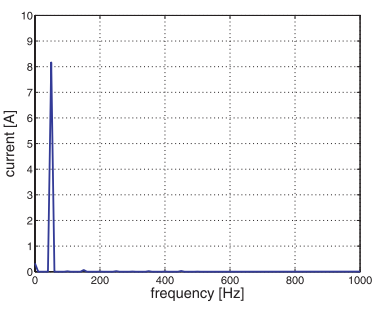

(c) With AF. (FB-type)

Fig. 13. FFT analysis $i_{s}$ (Experiment).

Fig. 9(c) の FB 型補償では奇数次の高調波成分を完全に抑 圧できていることが確認できる。また，FF 型補償と FB 型 補償それぞれの AF 出力電流を表したものが Fig. 10(a), (b) であり， $i_{a f}$ が指令值に追従していることがわかる。

〈6・2〉 実験実験では, エヌエフ回路設計ブロッ ク社製のシステム交流電源 (P-STATION/4471 インターフェ イス）を用い，AF の制御は TEXAS INSTRUMENTS 社製 の DSP (C6713) によるディジタル制御装置を利用してい る。Fig. 11 は実験装置の写真である。

実験ではセンサーからの微小なノイズが発生することが ある。このノイズは次数間高調波成分を含んでいるため, 前章で述べたように FB 型では増幅させてしまう恐れがあ
る。実際にノイズ対策を行わずに FB 型補償を行った場合, 電流波形は大きく発散してしまうことを確認した。

そこで，これを取り除くために Q フィルタを用いる。

$$
Q[z]=\left(\frac{z+\gamma+z^{-1}}{\gamma+2}\right)^{N_{q}}
$$

このフィルタは位相遅れ無しのローパスフィルタである。 今回の実験では $\gamma=2, N_{q}=2$ とし, カットオフ周波数が 約 $850 \mathrm{~Hz}$ となるように設計した。

Fig. 12(a)，(b)，(c) はシミュレーションと同様にAF を 動作させたときの実験結果で, Fig. 13(a)，(b)，(c) はそれ ぞれを FFT 解析した結果である。シミュレーション結果と 


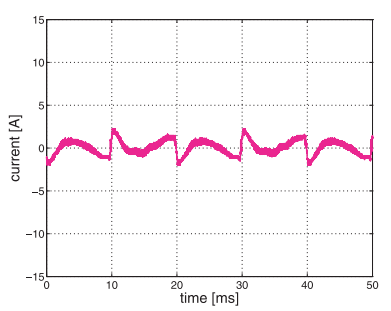

(a) FF-type

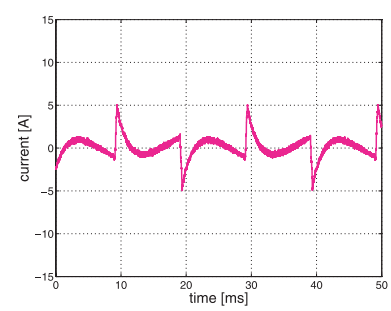

(b) FB-type
Fig. 14. AF current $i_{a f}$ (Experiment).

ほぼ同様に，FF 型補償ではある程度高調波を抑圧できてお り, FB 型補償では繰り返して補償することにより奇数次の 高調波を抑圧できていることが確認できる。なお，そのと きの $\mathrm{AF}$ 電流が Fig. 14(a), (b) である。

\section{7. おわりに}

本稿では，AF のディジタル電流制御に PTCを用いた。 その指令值生成の際，高調波が周期的であることを利用し た補償信号生成において FF 型と FB 型という 2 種類につ いての方法を提案し，シミュレーションと実験を通してそ の有効性を確認した。

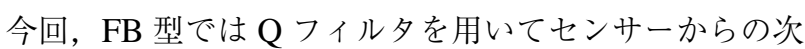
数間高調波成分を含んだノイズの増幅を抑えた。しかし， 長時間 FB 型を用いると次数間高調波は次第に悪化してし まう。一方, FF 型では抑圧特性が悪化することは無い ${ }^{(13)}$ 。 そのため, FB 型で一定時間経過後にスイッチをオフにし， 途中から FF 型に切り替えることで高調波補償とノイズ対 策の 2 つを同時に達成することができる。

(平成 20 年 12 月 1 日受付, 平成 21 年 8 月 16 日再受付)

\section{文献}

（1）赤木泰文，他：「多重電圧形 PWM 変換器を用いた高調波抑制用ア クティブフィルタ」,電学論 B, Vol.105, pp.573-580 (1985)

(2) F.Z. Peng, M. Kohata, and H. Akagi: "Compensation Characteristics of Shunt Active and Power Filters", T. IEE Japan, Vol.113-D, No.1, pp.33-39 (1993) (in Japanese)

(3) T. Ohnishi: "Single Phase Line Current Compensator based on AC Line Current Detection", T. IEE Japan, Vol.117-D, No.3, pp.321-327 (1997) (in Japanese)

(4) K. Hirasaki and H. Fujita: "A Fast Current Controller Based on Oversampling and its Application to a Single-Phase Active Filter", SPC-07-27, pp.37-42 (2007) (in Japanese)

(5) S. Hamasaki and A. Kawamura: "A Novel Method for Active Filter Current Regulation using Dead-beat Control”, T. IEE Japan, Vol.122-D, No.8, pp.781-789 (2002) (in Japanese)

(6) L. Zhao and A. Kawamura: "Current Control for Active Filter with Multirate and Deadbeat Control", JIASC2004, 1-102, pp.489-490 (2004-9) (in Japanese)

(7) K. Ishihara and A. Kawamura: "DSP Based Real Time Output Waveform Synthesis for Three Phase PWM Inverter", T. IEE Japan, Vol.110-D, No.6, pp.627-636 (1990) (in Japanese)

(8) K.J. Åström, P. Hangander, and J. Sternby: "Zeros of Sampled Systems", Automatica, Vol.20, No.1, pp.31-38 (1984)

9) D. Ogino, H. Fujimoto, and S. Kondo: "Multirate Two-degree-of-freedom Deadbeat Control of Single-phase Inverter", T. IEE Japan, Vol.125-D, No.7, pp.751-757 (2005) (in Japanese)

10) H. Fujimoto, Y. Hori, and A. Kawamura: "Perfect Tracking Control Method Based on Multirate Feedforward Control", Trans. SICE, Vol.36, No.9, pp.766-772 (2000) (in Japanese)

(11) K. Sato and H. Fujimoto: "Proposal of Current Control for Single-Phase Active Filter Based on Multirate PWM", IECON, pp.3155-3160 (2008)

(12) K.P. Gokhale, A. Kawamura, and R.G. Hoft: "Dead beat microprocessor control of PWM inverter for sinusoidal output waveform synthesis", IEEE Trans. Industry Applications, Vol.23, No.5, pp.901-910 (1987)

(13) T. Nakai and H. Fujimoto: "Proposal of harmonic current suppression method of PM motor based on repetitive perfect tracking control", SPC07-27, pp.37-42 (2007) (in Japanese)

佐 藤 公 彦 (学生員) 1984 年 9 月 23 日生。 2007 年 3 月横 浜国立大学工学部電子情報工学科卒業。現在，同 大学大学院工学府物理情報工学専攻電気電子ネッ トワークコース在学中。インバータを用いた電圧, 電流制御に従事。IEEE 学生会員。

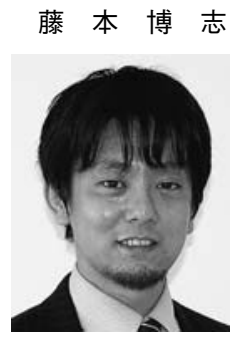

（正員） 1974 年 2 月 3 日生。 2001 年 3 月東京 大学大学院工学系研究科電気工学専攻博士課程修 了。博士 (工学)。同年 4 月長岡技術科学大学工 学部電気系助手。2002 年 8 月より 1 年間, 米国 Purdue 大学工学部機械工学科客員研究員。2004 年 4 月横浜国立大学大学院工学研究院講師。2005 年 4 月同助教授, 2007 年 4 月同准教授。制御工 学，モーションコントロール，マルチレート制御 に関する研究に従事。2001 年 IEEE Trans. IE 最優秀論文賞などを受 賞。計測自動制御学会, 自動車技術会, IEEE 各会員。 